Article

\title{
Problem Orientated Analysis on China's Shale Gas Policy
}

\author{
Zhong Wang ${ }^{1} \mathbb{D}$, Yuyan Luo ${ }^{1,2, *}$, Pengchong $\mathrm{Li}^{1}$ and Xiaoqian Cai ${ }^{1}$ \\ 1 College of Management Science, Chengdu University of Technology, Chengdu 610059, China; \\ wangzhong2012@mail.cdut.edu.cn (Z.W.); lipengchong89@126.com (P.L.); xiaoqiancai00@163.com (X.C.) \\ 2 Post-doctorate R\&D Base of Management Science and Engineering, Chengdu University of Technology, \\ Chengdu 610059, China \\ * Correspondence: luoyuyan13@mail.cdut.edu.cn; Tel.: +86-138-8060-6865
}

Received: 15 August 2018; Accepted: 28 October 2018; Published: 31 October 2018

\begin{abstract}
China has accelerated the pace of shale gas development from 2010. A series of policies were issued by the Chinese government to motivate and regulate shale gas exploration and exploitation. In order to investigate the effectiveness of these policies and provide reference to the policymakers, the most relevant policies from 2010 to 2016 were collected and analyzed. Our study summarized that, in total, eight government agencies issued 25 related policies, which cover all the main problems that impede China's shale gas industry. With the aid of these policies, the approved research and development (R\&D) funds exceed 350 million Chinese yuan (CNY) (\$55 million), and over 80 domestic companies participated in exploration rights bidding and nine foreign companies initiated thirteen international cooperation projects. In 2016, China's shale gas production reached $7.88 \times 10^{9} \mathrm{~m}^{3}$, ranking third in the world. However, these policies still have some shortcomings, such as low environmental concerns, weak financial stimulus, and inefficient implementation. Therefore, we suggest that future policy should put particular emphasis on (1) formulating special environmental regulations and determining development scale based on water resource; (2) providing detailed implementation plans and maintaining stable subsidy; (3) enhancing communication and supervision; and (4) establishing a public big data platform.
\end{abstract}

Keywords: China; shale gas development; Chinese energy policy; main problems of shale gas industry; policy statistics and analysis; policy recommendations

\section{Introduction}

China is one of the largest energy consumers in the world, and more than $68 \%$ oil and $38 \%$ of consumed natural gas were imported in 2017. Since coal still accounts for $60 \%$ of China's energy structure, China emitted $9.2 \times 10^{9} \mathrm{t} \mathrm{CO}_{2}$ in 2017, thus becoming one of the largest anthropogenic $\mathrm{CO}_{2}$ emitters in the world [1]. How to guarantee energy security and optimize energy structure is one of the toughest questions that Chinese government faces. The "shale gas revolution" might shed some light on this question. Relying on shale gas production, the United States further strengthens its energy security and would become a net natural gas exporter [2]. In addition, the lifecycle $\mathrm{CO}_{2}$ emissions of shale gas are $23 \%$ and $33 \%$ lower than that of gasoline and coal, respectively [3]. Due to a shift in generation mix from coal to natural gas and renewables, the power sector of the United States reduced $\mathrm{CO}_{2}$ emission drastically since 2005 [4]. China has abundant shale gas resources [5,6], and began to explore and exploit shale gas on a large-scale from 2010. Within 10 years, China made significant progress in shale gas development, and became the largest shale gas producer following the United States and Canada [7-9]. Since shale gas is different from conventional natural gas in terms of forming condition and distribution characteristics [10], the development cost and risk are much 
higher. Therefore, at the early stage of the shale gas industry, the motivation and regulation by the government are very important. Some studies pointed out that the success of the shale gas revolution in North America was indispensable to the support from the government, so the Chinese government should publish appropriate incentive policies to promote its shale gas industry, which was still in its infancy [11-14]. Thereafter, more studies focused on this field. Due to the high cost of developing shale gas, some studies discussed this topic from an economic perspective (e.g., tax concession and financial subsidies [15-17], market regulation, and competition [18-20]). In their perspectives, under China's current technological and economic conditions, it was difficult to make a profit; therefore, policymaking should focus on cost reduction in order to attract investors. With the rising awareness of environment, some studies focused on the negative impacts to the environment and residents in shale gas development (e.g., drinking water contamination, water waste, noise, and geological disruption), and put forward some advice about policymaking on the perspective of water resource protection and environmental risk reduction [21-23]. In addition, some research studied this topic from a comprehensive view, taking market prospects, environmental impacts, conditions of resource, and general conditions of extraction and utilization, into account [24-27]. They suggested that the policy instruments should consider all aspects, such as gas price regulation, financial subsidies, corporate income taxes reduction, or their combinations.

In reality, China has issued serials of relevant policies and regulations to motivate and regulate shale gas development from 2010. Despite some significant progress having been made, the development of China's shale gas industry is lower than expected, and the production target in 2020 was reduced from $60 \times 10^{9} \mathrm{~m}^{3}$ to $30 \times 10^{9} \mathrm{~m}^{3}$ in the Shale Gas Development Plan (2016-2020) [28]. To our best knowledge, few studies have focused on the existing policies and investigated their effectiveness comprehensively. Moreover, the policies recommended by previous studies are almost based on the comparison between the United States and China, though the resources and industrial conditions of the two countries are different, so the United States' experience may not be fully applicable to China.

The aim of this paper is to investigate the effectiveness and shortcomings of the issued policies, in the hope it could provide some references to policymakers. Therefore, this paper focuses on the existing policies and the actual situation of China's shale gas industry. Firstly, the main problems that hinder the development of China's shale gas industry at the initial stage were summarized. Secondly, the most relevant policies issued from 2010 to 2016 were collected. Then, the main problems were taken as a guide to analyze the effects and shortcomings of these policies. Finally, some specific policy suggestions are proposed, and a general conclusion was drawn.

\section{Main Problems of China's Shale Gas Industry}

At the initial stages of China's shale gas industry, some problems of technology, cost, and market impeded the development of China's shale gas industry.

\subsection{Lack of Core Technologies}

The key technologies of shale gas development are horizontal drilling, multistage fracturing of horizontal wells, and microseismic monitoring. Before 2010, however, China did not own these technologies, and also lacked experience in exploration and exploitation. In order to obtain advanced technologies and experience quickly, China's state-owned oil companies joined hands with international oil companies to develop domestic shale gas blocks together and, meanwhile, acquire overseas shale gas assets directly [29]. Through international cooperation, China has gradually mastered some technologies of shale gas exploration and exploitation, and realized equipment localization. However, China does not yet have complete process core technologies. For example, until 2013, China has not mastered the technologies of microseismic monitoring, production dynamic prediction, and micro/nano 3D reconstruction, etc. Moreover, equipment of rotary geological steering, 
sliding sleeve fracturing, microstructure, and composition analysis of micro/nanoscale have not yet achieved localization [30,31].

\subsection{High Production Costs}

First of all, China's shale is deeply buried. The depth of shale in the United States is usually from $800 \mathrm{~m}$ to $2000 \mathrm{~m}$ while, in China, it is more than $3000 \mathrm{~m}$ [32]. Secondly, compared with other countries that are rich in shale gas resource, the distribution of the shale gas in China is more uneven, and the geological condition is more complex [33]. Thirdly, most of China's shale gas resource is distributed in mountainous regions of southwest China, which is facing drought and seasonal water shortage. Fourthly, lack of core technologies pushes up total development costs. Therefore, China's drilling and fracturing costs are much higher. Take Fuling shale gas field as an example, which is China's first large shale gas field. In 2012, its average well cost was about \$16 million, which was 2.5 times higher than Marcellus play, and 5 times higher than Barnett play in North America [34]. In addition, a single well production of shale gas declines rapidly during the first year or two, so a large number of wells are needed for stable output, which would lead to high total investment and a long payback period.

\subsection{Low Market Activity}

Over 7900 small-and medium-sized enterprises (SMEs) participated in the shale gas industry of the United States [35], and fierce competition led to technology innovation and costs reduction. The activity of SMEs, to some extent, has led to the vigorous development of the shale gas industry in the United States whereas, in China, SMEs and private enterprises were absent in the shale gas market. The main obstacles are that (1) the threshold of project administration and approval is quite high, especially for private enterprises; (2) the energy price mechanism is rigid, which makes the profitability uncertain and the risks uncontrollable; and (3) some critical areas are monopolized, such as oil and gas pipelines [36]. Thus, the exploration and production of shale gas in China is basically monopolized by a handful of large state-owned enterprises. In the first round of auctions on exploration rights for shale gas blocks in 2011, only six large state-owned companies participated in the bidding, and SMEs or private enterprises did not even participate. However, after obtaining the exploration rights, some large state-owned enterprises have not fulfilled their mining commitments; they just enclose the blocks and do not carry out the exploration immediately.

\subsection{High Environmental Burden}

First of all, shale gas development consumes a lot of water, which is almost 10 times larger than that in conventional natural gas development. According to the Department of Energy of the United States, the average water consumption of a single well in the United States is $10,000-15,000 \mathrm{~m}^{3}$ [37]. As China's shale gas is buried much deeper than the United States, the water consumption is much higher. If China's shale gas production achieves the target of $30 \times 10^{9} \mathrm{~m}^{3}$ in 2020, the estimated water consuming in drilling and fracturing will reach at $209 \times 10^{6}-293 \times 10^{6} \mathrm{~m}^{3}$ [38]. Moreover, about $40 \%$ of shale gas reserves are located in the central and western regions in China, where drought and seasonal water shortage are common [39]. Secondly, because hydraulic fracturing is widely used in shale gas development, it is possible for methane and fracking chemicals to enter shallow aquifers and contaminate the drinking water, which has become a hot-button issue in the United States. In China, most shale gas resource-rich areas are located in hilly and mountainous terrains, where faults and cracks are numerous and complex. Therefore, it is easier for methane and fracking chemicals to enter drinking water aquifers, which would worsen China's surface water and groundwater pollution situation. Furthermore, due to China's high population density, shale gas development will cause other environmental problems such as air pollution, habitat fragmentation, and community disruption [21].

Moreover, China has no special laws aiming at environmental protection in oil and gas development, not to speak of shale gas exploration and exploitation. Even existing environment-related 
laws are not always strictly enforced in China. Thus, developing shale gas on a commercial scale poses a great challenge to China's fragile ecological environment.

\section{Policy Analysis and Discussion}

Since the 1970s, the United States has issued a series of supportive policies that cover various aspects of shale gas development, such as financial subsidies, tax relief, and market competition, which have contributed to the prosperity of the shale gas industry. In order to promote shale gas industry in China, the Chinese government has also published a series of policies.

\subsection{Policy Statistics and Analysis}

From 2010 to 2016, eight government agencies issued 25 relevant policies (Table 1). Shale gas development and utilization involves participations of many sectors, so the promotion of the shale gas industry requires relevant departments to cooperate and coordinate with each other. According to Table 1, there are 19 policies issued by a single agency (each policy has only one publisher) and 6 policies were joint released by several agencies, such as Policy No. 4, No. 5, and No. 6. MLR and NEA are competent government agencies which take charge of resource and energy, therefore, most of these policies were issues by them. MLR issued 8 policies alone, and 3 policies with other agencies. NEA issued 5 policies alone, and 3 policies with others. Since financial incentive is very important at the initial stage of the shale gas industry, MOF issued 4 policies with other agencies, just behind MLR, NEA, and NDRC. In terms of the contents of policies, the State Council makes a strategy or plan from a macro level, NDRC shapes the overall policy, MLR and NEA mainly concentrate on mining rights bidding, technology innovation, and industry standards, MOF and SAT determine the subsidies and tax incentives, and MOC and ACFIC bring foreign and private capital into the domestic market.

Table 1. Shale gas-relevant policies in China.

\begin{tabular}{|c|c|c|c|c|}
\hline Number & Date & Name & Publisher & Functions and Comments \\
\hline 1 & 2010.07 & $\begin{array}{l}\text { Notice on Establishment of } 22 \\
\text { National Energy R\&D (Experimental) } \\
\text { Centers [40] }\end{array}$ & NEA $^{1}$ & Establishing shale gas R\&D institutes. \\
\hline 2 & 2011.06 & $\begin{array}{l}\text { Public Bidding for Mineral } \\
\text { Exploration Rights of Oil \& Gas [41] }\end{array}$ & $\mathrm{MLR}^{2}$ & $\begin{array}{l}\text { Transferring shale gas exploration rights } \\
\text { through public tender for the first time. }\end{array}$ \\
\hline 3 & 2011.12 & $\begin{array}{l}\text { Bulletin of New Discovered Mineral } \\
\text { Species (No. } 30 \text { of 2011) [42] }\end{array}$ & MLR & $\begin{array}{l}\text { Categorizing shale gas as the } 172 \mathrm{nd} \\
\text { independent mineral species in China. }\end{array}$ \\
\hline 4 & 2011.12 & $\begin{array}{l}\text { Catalogue for the Guidance of } \\
\text { Foreign Investment Industries } \\
\text { (Amended in 2011) [43] }\end{array}$ & $\mathrm{NDRC}^{3}, \mathrm{MOC}^{4}$ & $\begin{array}{l}\text { Encouraging foreign investment in shale } \\
\text { gas resources development (limited to joint } \\
\text { ventures and cooperation). }\end{array}$ \\
\hline 5 & 2012.03 & $\begin{array}{l}\text { Shale Gas Development Plan } \\
(2011-2015) \text { [28] }\end{array}$ & $\begin{array}{l}\text { NDRC, } \mathrm{MOF}^{5} \\
\text { MLR, NEA }\end{array}$ & $\begin{array}{l}\text { Making a comprehensive plan for shale gas } \\
\text { development in the period of 2011-2015. }\end{array}$ \\
\hline 6 & 2012.06 & $\begin{array}{l}\text { Opinion on Further Encouraging and } \\
\text { Guiding Private Capital Investment in } \\
\text { the Field of Land and Resources [44] }\end{array}$ & MLR ACFIC $^{6}$ & $\begin{array}{l}\text { Encouraging private capital to invest in } \\
\text { shale gas exploration and exploitation. }\end{array}$ \\
\hline 7 & 2012.06 & $\begin{array}{l}\text { Notice on Agreeing to Establish } 46 \\
\text { Key Laboratory of MLR [45] }\end{array}$ & MLR & $\begin{array}{l}\text { MLR establish } 46 \text { key laboratory of } \\
\text { shale gas. }\end{array}$ \\
\hline 8 & 2012.09 & $\begin{array}{l}\text { The announcement of Public Tender } \\
\text { of Shale Gas Exploration Rights [46] }\end{array}$ & MLR & $\begin{array}{l}\text { Transferring shale gas exploration rights } \\
\text { again and this tender open to foreign and } \\
\text { private companies. }\end{array}$ \\
\hline 9 & 2012.10 & $\begin{array}{l}\text { Notice on Improving the Level of } \\
\text { Mineral Resources Saving and } \\
\text { Comprehensive Utilization by } \\
\text { Promoting Advanced and Applicable } \\
\text { Technologies [47] }\end{array}$ & MLR & $\begin{array}{l}\text { Taking shale gas as one of the key areas and } \\
\text { making great efforts to promote the } \\
\text { high-efficient developing technology. }\end{array}$ \\
\hline 10 & 2012.10 & $\begin{array}{l}\text { The 12th Five-Year Plan of Natural } \\
\text { Gas Development [48] }\end{array}$ & NDRC & $\begin{array}{l}\text { Taking shale gas as an important part in } \\
\text { natural gas development in the period of } \\
\text { 2011-2015. }\end{array}$ \\
\hline
\end{tabular}


Table 1. Cont.

\begin{tabular}{|c|c|c|c|c|}
\hline Number & Date & Name & Publisher & Functions and Comments \\
\hline 11 & 2012.11 & $\begin{array}{l}\text { Notice on Introduction of Financial } \\
\text { Subsidy Policy for Shale Gas } \\
\text { Development and Utilization [49] }\end{array}$ & MOF, NEA & $\begin{array}{l}\text { Central government providing financial } \\
\text { subsidy for shale gas production from } 2012 \\
\text { to } 2015 \text {, and the standard is } 0.4 \mathrm{CNY} / \mathrm{m}^{3} \\
\left(0.06 \$ / \mathrm{m}^{3}\right) \text {. }\end{array}$ \\
\hline 12 & 2012.11 & $\begin{array}{l}\text { Notice on Strengthening the } \\
\text { Exploration \& Exploitation of Shale } \\
\text { Gas and Relevant Supervision and } \\
\text { Administration Work [50] }\end{array}$ & MLR & $\begin{array}{l}\text { - Promoting shale gas exploration and } \\
\text { exploitation through multiply ways. } \\
\text { - Strengthening supervision in aspect in } \\
\text { environmental pollution. }\end{array}$ \\
\hline 13 & 2013.04 & $\begin{array}{l}\text { Special funds management approach } \\
\text { for Mineral Source Saving and } \\
\text { Comprehensive Utilization [51] }\end{array}$ & MOF, MLR & $\begin{array}{l}\text { Providing special research fund for } \\
\text { shale gas. }\end{array}$ \\
\hline 14 & 2013.05 & $\begin{array}{l}\text { Announcement on Value Added Tax } \\
\text { Treatments Related to the } \\
\text { Development of Coalbed Methane } \\
\text { and Shale Gas by Oil and Gas } \\
\text { Companies [ } 52 \text { ] }\end{array}$ & $\mathrm{SAT}^{7}$ & $\begin{array}{l}\text { Clarifying value added tax (VAT) of shale } \\
\text { gas exploitation and related service is } 17 \% \text {, } \\
\text { and VAT of Sino-foreign joint exploitation } \\
\text { is } 5 \% \text {. }\end{array}$ \\
\hline 15 & 2013.10 & Shale Gas Industry Policy [53] & NEA & $\begin{array}{l}\text { Providing an overall thought and specific } \\
\text { provisions of shale gas industry. }\end{array}$ \\
\hline 16 & 2014.02 & $\begin{array}{l}\text { Regulation on Openness of Oil \& Gas } \\
\text { Pipeline Facilities (Trial) [54] }\end{array}$ & NEA & $\begin{array}{l}\text { Opening the oil \& gas pipeline facilities to } \\
\text { other market entities equally. }\end{array}$ \\
\hline 17 & 2014.03 & $\begin{array}{l}\text { Construction and Operation } \\
\text { Management Measures of Natural } \\
\text { Gas Infrastructure [55] }\end{array}$ & NDRC & $\begin{array}{l}\text { Encouraging and supporting open and } \\
\text { interconnection of natural gas } \\
\text { infrastructures. }\end{array}$ \\
\hline 18 & 2014.04 & $\begin{array}{l}\text { Technological Specification for Shale } \\
\text { Gas Resources/Reserves Calculation } \\
\text { and Evaluation [56] }\end{array}$ & MLR & $\begin{array}{l}\text { The first industry standard of shale gas, } \\
\text { which clarifying the definition of reserve, } \\
\text { and stipulating the evaluation methods of } \\
\text { resources or reserves. }\end{array}$ \\
\hline 19 & 2014.06 & $\begin{array}{l}\text { Energy Development Strategy Action } \\
\text { Plan (2014-2020) [57] }\end{array}$ & $\mathrm{SC}^{8}$ & $\begin{array}{l}\text { - Taking shale gas as one of the } 20 \text { key } \\
\text { innovation directions. } \\
\text { - Reforming natural gas price mechanism. }\end{array}$ \\
\hline 20 & 2014.10 & $\begin{array}{l}\text { Bulletin of the Final Results of } \\
\text { Expired Shale Gas Exploration Rights } \\
\text { by Public Tender [58] }\end{array}$ & MLR & $\begin{array}{l}\text { Punishing two companies which did not } \\
\text { make the committed investment during the } \\
\text { exploration period. }\end{array}$ \\
\hline 21 & 2015.04 & $\begin{array}{l}\text { Notice on Financial Subsidy Policy for } \\
\text { Shale Gas Development and } \\
\text { Utilization [59] }\end{array}$ & MOF NEA & $\begin{array}{l}\text { Providing financial subsidy, and the } \\
\text { standard is } 0.3 \mathrm{CNY} / \mathrm{m}^{3}\left(0.05 \$ / \mathrm{m}^{3}\right) \text { from } \\
2016 \text { to } 2018 \text {, and } 0.2 \mathrm{CNY} / \mathrm{m}^{3}\left(0.03 \$ / \mathrm{m}^{3}\right) \\
\text { from } 2019 \text { to } 2020 \text {. }\end{array}$ \\
\hline 22 & 2015.11 & $\begin{array}{l}\text { NEA Announcement No. } 6 \text { of } \\
2015 \text { [60] }\end{array}$ & NEA & Approving 10 industry standards. \\
\hline 23 & 2016.07 & $\begin{array}{l}\text { The 13th Five-Year Plan of National } \\
\text { Science \& Technology Innovation [61] }\end{array}$ & SC & Committing research funds for shale gas. \\
\hline 24 & 2016.09 & $\begin{array}{l}\text { Shale Gas Development Plan } \\
(2016-2020) \text { [62] }\end{array}$ & NEA & $\begin{array}{l}\text { Making a comprehensive plan for shale gas } \\
\text { development in the period of } 2016-2020 \text {. }\end{array}$ \\
\hline 25 & 2016.12 & $\begin{array}{l}\text { The 13th Five-Year Plan of Natural } \\
\text { Gas Development [63] }\end{array}$ & NDRC & $\begin{array}{l}\text { Taking shale gas as an important part in } \\
\text { natural gas development in the period of } \\
\text { 2016-2020. }\end{array}$ \\
\hline
\end{tabular}

${ }^{1}$ NEA: National Energy Administration. ${ }^{2}$ MLR: Ministry of Land and Resources. ${ }^{3}$ NDRC: National Development and Reform Commission. ${ }^{4}$ MOC: Ministry of Commerce of China. ${ }^{5}$ MOF: Ministry of Finance. ${ }^{6}$ ACFIC: All-China Federation of Industry and Commerce. ${ }^{7}$ SAT: State Administration of Taxation. ${ }^{8}$ SC: State Council.

The correspondence between the contents of each policy and the main problems of China's shale gas industry is discussed, and the results are shown in Table 2. The table shows that all the main problems have been covered by the issued policies. Some policies just cover only one problem, such as Policy No. 1, No. 2, and No. 20, whereas other policies cover two or more problems, such as Policy No. 5, No. 10, and No. 19. If considering the former type as a specific policy, and the latter type as a mixed policy, there are seventeen specific policies and eight mixed policies. 
Table 2. The correspondence between policies and main problems.

\begin{tabular}{|c|c|c|c|c|c|c|c|c|c|c|c|c|c|c|c|c|c|c|c|c|c|c|c|c|c|}
\hline \multirow{2}{*}{ Problems } & \multicolumn{25}{|c|}{ Policy Number } \\
\hline & 1 & 2 & 3 & 4 & 5 & 6 & 7 & 8 & 9 & 10 & 11 & 12 & 13 & 14 & 15 & 16 & 17 & 18 & 19 & 20 & 21 & 22 & 23 & 24 & 25 \\
\hline Technology & $\bullet$ & & & & $\bullet$ & & $\bullet$ & & $\bullet$ & $\bullet$ & $\bullet$ & & $\bullet$ & . & $\bullet$ & & & • & • & & & & $\bullet$ & & $\bullet$ \\
\hline Market & & - & - & - & $\bullet$ & - & & - & & $\bullet$ & & - & & & $\bullet$ & - & - & & & - & & & & & $\bullet$ \\
\hline Environment & & & & & - & & & & & - & & - & & & - & & & & & & & & & & - \\
\hline
\end{tabular}

Despite that all the problems have been covered in issued policies, the degree of attention to each problem is different. Among the specific policies, six policies correspond to the technology issue, three policies focus on the cost issue, eight policies are concerned with the market issue, but no policies pay close attention to the environmental issue. Giving consideration to both specific and mixed policies, there are fourteen, ten, fifteen, and six policies corresponding to technology, cost, market, and environmental issues respectively, as Figure 1 shows.

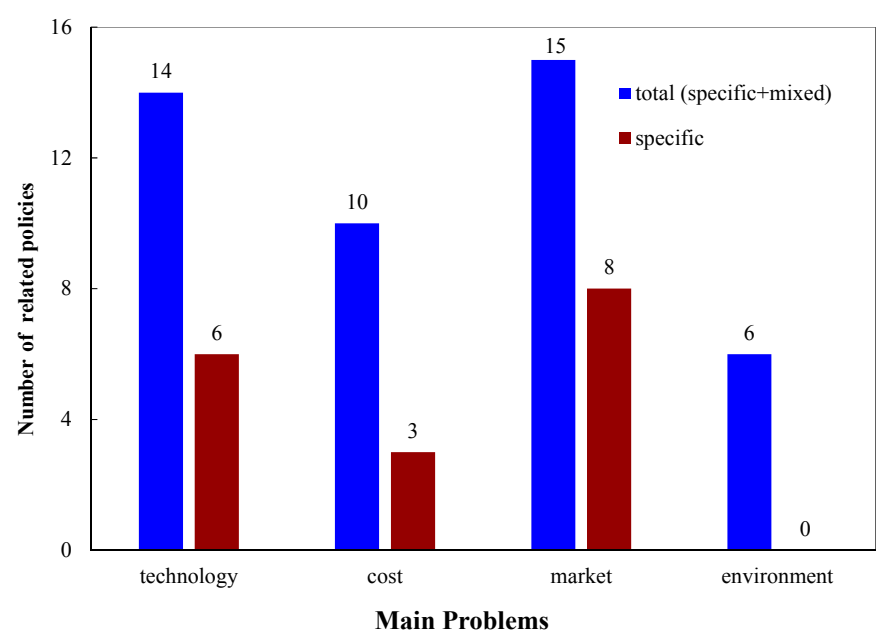

Figure 1. Issued policies covered all the main problems but to different degrees.

Further analysis is integrated with issue date (Figure 2). The policymakers focused on the problems of technology and market from 2010, and published relevant policies almost every year. However, the policymakers paid very limited attention to the problems of the environment, and relevant policies are issued only in 2012, 2013, and 2016.

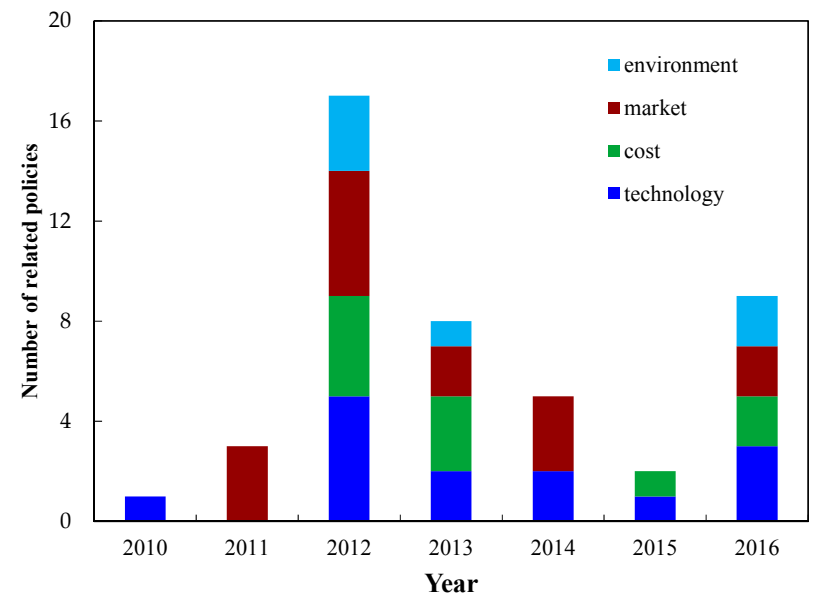

Figure 2. Technology and market issues are always the focus of policymakers between 2010 and 2016, while the environmental issue gets little concern. 


\subsection{Policy Effectiveness Analysis}

Under policy stimulus and promotion, the main problems and barriers that impede the development of China's shale gas industry have been partially solved, and the development of the shale gas industry is showing a good trend.

\subsubsection{Core Technology Makes a Breakthrough}

Under the guidance of relevant policies, China has established several specific scientific research institutes which focus on core technologies of shale gas development, such as National Energy Shale Gas R\&D (Experimental) Center, Key Laboratory of Shale Gas Exploration of MLR, and Key Laboratory of Sale Gas Resource Strategic Evaluation of MLR. On the other hand, the Chinese Ministry of Science and Technology (MOST) has set up several major research programs to fund R\&D for shale gas development. For example, the National Program on Key Basic Research Project (973 Program) approved three shale gas related projects in 2012, 2013, and 2014, which were Basic Research on Efficient Development of Marine Shale Gas in China Southern Region, Enrichment Mechanism and Resource Potential Assessment of Paleozoic Shale Gas in China Southern Region, and Supercritical Carbon Dioxide Enhance Shale Gas Efficient Development. The total funding would exceed 100 million CNY (\$15.63 million).

In order to achieve national goals through core technology breakthrough and resource integration, the Chinese government initiated the National Science and Technology Major Project in 2006. This project has 16 major areas, and each area would be funded with nearly 10 billion CNY ( $\$ 1.56$ billion) from 2006 to2020. Large Oil \& Gas Field and Coalbed Methane (CBM) Development was identified as one of the major areas, and five shale gas-related subprojects were approved in 2017. The total funding was nearly 95 million CNY (\$14.84 million).

Moreover, the National Natural Science Foundation of China (NNSFC) also took shale gas as one of the key funding areas from 2010, when China began to develop shale gas on a commercial scale (shown in Figure 3). By statistics, NNSFC has approved 181 concerning programs from 2010 to 2016, and the total funding exceeds 150 million CNY (\$23.44 million). Comparing Figure 2 with Figure 3, with a large number of policies issued in 2012, the shale gas-related projects approved in 2012 have simultaneously increased by 3.5 times since 2011. The average projects approved exceed 30 per year, and the average funding per project reached 0.88 million CNY (\$0.14 million) from 2012.

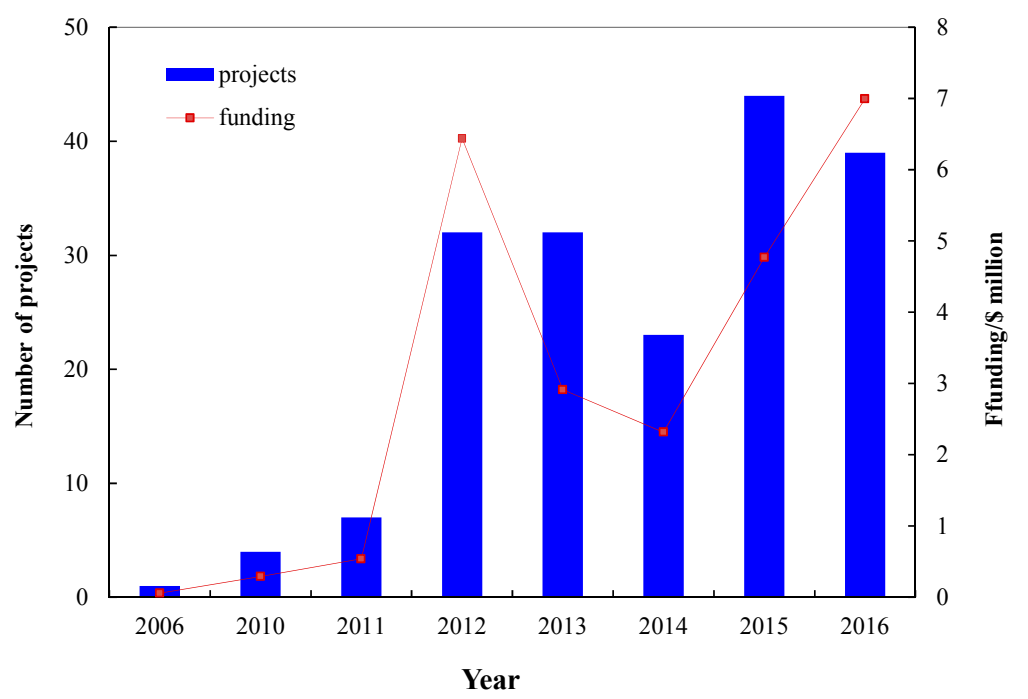

Figure 3. Shale gas-related research projects approved by NNSFC soared from 2010.

With the implementation of major R\&D projects and programs, China has basically mastered shale gas exploration and exploitation technologies, especially in the aspects of geophysics, drilling and 
completion, fracturing, and gas testing [64]. China is capable of accurately detecting the microseismic signal in exploration. Furthermore, China now is proficient in horizontal well drilling $(<3500 \mathrm{~m})$ and sectional fracturing, and the length of fracturing can reach $2130 \mathrm{~m}$ and 22 sections [9]. It is worth mentioning that China has made a breakthrough in the technology of dense shale fracturing. Given the characters of water shortage in northern China, Jilin Oilfield and Yantai Jereh Petroleum Equipment and Technologies Company have jointly developed carbon dioxide fracturing technology, which is more environmentally friendly compared to conventional hydraulic fracturing. This technique not only saves water, but also leaves no liquid or chemical damage in formation [65]. Besides technology, China also makes a breakthrough in key equipment manufacturing. At present, the movable drilling rig and SYL3000 fracturing truck, which are independently developed by China, have been applied in shale gas production [9].

\subsubsection{Market Activity Gradually Increases}

In order to stimulate more companies to enter the shale gas market, MLR holds two rounds of public bidding for shale gas exploration rights. In the first round in 2011, there were only four shale gas blocks and MLR invited only six large state-owned enterprises, including four oil companies and two CBM companies, which were China National Petroleum Corporation (CNPC), China Petroleum \& Chemical Corporation (Sinopec), China National Offshore Oil Corporation (CNOOC), Shanxi Yanchang Petroleum Group, China United Coalbed Methane Corporation, and Henan CoalBed Methane Company. Finally, Sinopec and Henan CoalBed Methane Company won two out of the four available blocks. In the second round in 2012, the shale blocks increased to 20, and MLR greatly reduced the threshold for bidders, and opened the tender to private firms and certain Sino-foreign joint ventures. There were 83 firms, in total, participating in the second round, of which nearly one-third were private firms. In the end, two private enterprises won two blocks. Compared with the first round of tender, the second round of tender was more competitive. On average, four firms competed for one block, and 7.6 bidding documents were received for one block. The comparison between the first and the second round of tender is shown in Table 3.

Table 3. The comparison between the first and the second round of tender.

\begin{tabular}{|c|c|c|c|}
\hline & Items & The First Round & The Second Round \\
\hline \multicolumn{2}{|c|}{ Total shale gas blocks } & 4 & 20 \\
\hline \multicolumn{2}{|c|}{ Blocks of failed bidding } & 2 & 1 \\
\hline \multirow{4}{*}{ Competitors } & Central state-owned enterprise & 4 & no details \\
\hline & Local state-owned enterprise & 2 & no details \\
\hline & Private enterprise & 0 & about 26 \\
\hline & Sum & 6 & 83 \\
\hline \multirow{4}{*}{ Winners } & Central state-owned enterprise & 1 & 6 \\
\hline & Local state-owned enterprise & 1 & 8 \\
\hline & Private enterprise & 0 & 2 \\
\hline & Sum & 2 & 16 \\
\hline \multirow{2}{*}{ Documents } & Total & 9 & 152 \\
\hline & Per block & 2.25 & 7.60 \\
\hline \multirow{2}{*}{ Investment } & Total $/ \$$ billion & 0.13 & 2.00 \\
\hline & Per block $/ \$$ billion & 0.03 & 0.10 \\
\hline
\end{tabular}

At the same time, encouraged by relevant policies, international oil companies accelerate their pace to enter China's shale gas market (shown in Figure 4). Since foreign companies are forbidden to develop and produce petroleum products independently in China, they had to build a joint venture with Chinese companies [66]. Though early in 2007, Newfield Exploration had cooperated with CNPC to prospect and evaluate the shale gas resource in the Weiyuan gas field in Sichuan Basin, 
the enthusiasm of foreign companies had not become high until 2010. According to Figure 4, before 2011, only four foreign companies (Newfield, Shell, British Petroleum (BP), and Hess) cooperated with Chinese firms and initiated five cooperation projects. With more policies published from 2011, more foreign companies, such as Total, Chevron, ExxonMobil, ConocoPhillips, and others, tried to enter China's shale gas market and, from 2011 to 2016, nine foreign companies have initiated 13 cooperation projects. It is worth mentioning that in 2016, BP signed its first and second shale gas production sharing contracts (PSA) in China. According to the PSAs, BP would explore, develop, and produce shale gas with CNPC in the Neijiang-Dazu block and Rong Chang Bei in the Sichuan Basin, covering an area of approximately $2500 \mathrm{~km}^{2}[67,68]$.

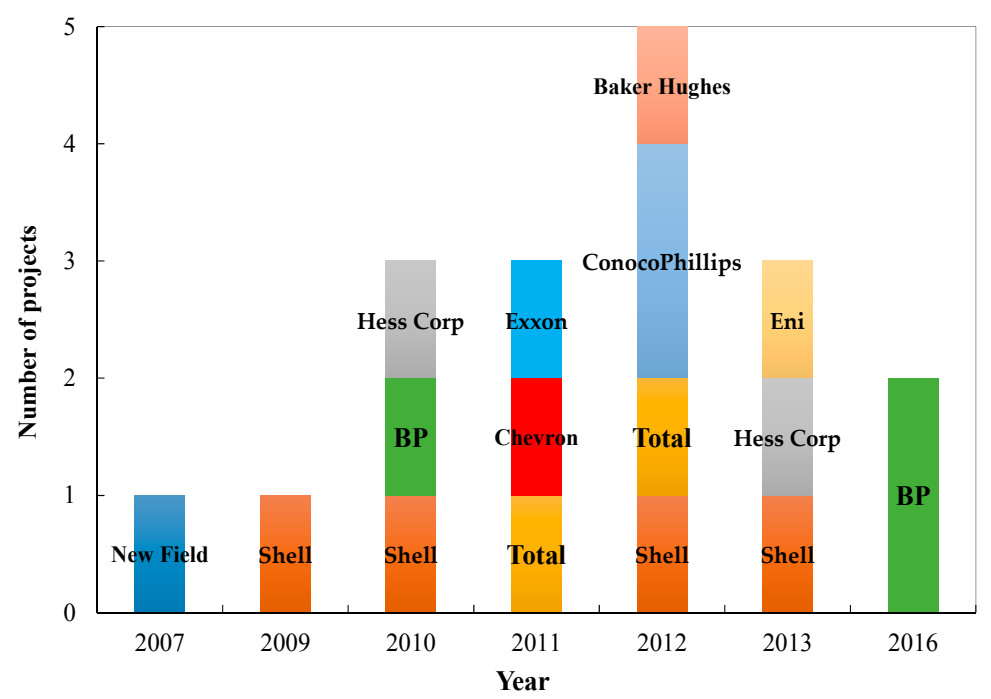

Figure 4. International cooperation in China's shale gas industry boomed in 2010, and reached a peak in 2012.

As illustrated in Table 3 and Figure 4, the issued policies successfully encouraged multiple kinds of enterprises, especially the private and foreign firms to enter China's shale gas industry.

\subsubsection{Costs Reduce and Production Increases}

Due to the breakthrough in core technologies and the experiences from international cooperation and actual operation, the drilling and completion cycle of the horizontal well had been reduced from 150 days to 70 days, and the shortest cycle was only 46 days. Correspondingly, the drilling cost also greatly declined. For example, the average cost was reduced by $23 \%$ to about $\$ 12$ million in the mid-2015, compared with the average cost of drilling a horizontal well in the Sichuan Basin in 2012 [69].

With the declining cost and increasing market activities, the production of shale gas has soared from 2012 (shown in Figure 5). It can be seen, from Figure 5, that shale gas production continuously increased from 2012 to 2016, and the average increase rate reached 390\%. With the high-speed growth, China's shale gas production reached $7.88 \times 10^{9} \mathrm{~m}^{3}$ in 2016, ranking third following the United States and Canada [70]. 


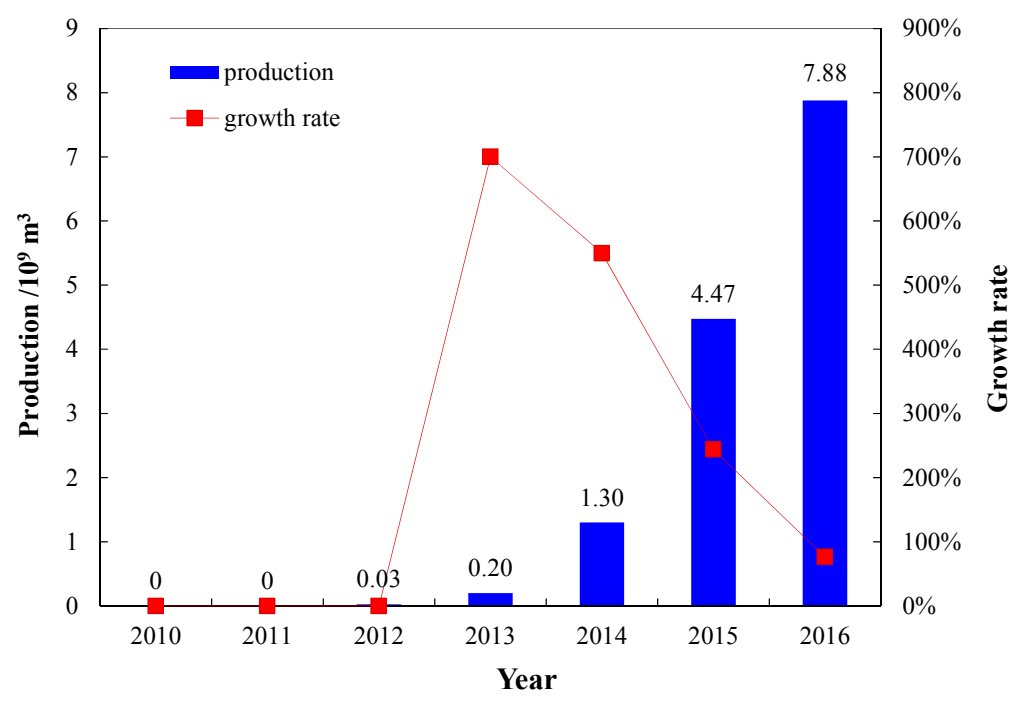

Figure 5. China's shale gas production increased rapidly from 2010 to 2016.

\subsection{Shortcomings of Policies}

\subsubsection{Insufficient Attention to Environmental Issues}

Firstly, only six policies were concerned about environmental issues, far below the number of policies that refer to the other three issues. Though NEA's Announcement on Shale Gas Industry Policy has a special chapter on energy conservation, water conservation, groundwater and soil protection, drilling fluid and fracturing fluid recycling, environmental impact assessment, and environmental regulation, it only acts as a principle regulation and lacks operability.

Secondly, China has no special laws or regulations on environmental protection in shale gas development. In 2014, the Ministry of Environment Protection of PRC published the draft of Standards of Industrial Pollutant Discharge for Oil \& Gas Exploitation Onshore but, until now, the official edition has not yet been released. Though China has several environmental protection laws and regulations that can be applied to oil and gas exploration and exploitation, such as Environmental Protection Law, Water Pollution Prevention and Control Law, Mineral Resource Law, Water Law, and so on, all of them are lack pertinence. Due to the complicated nature of the problems, such as fracturing fluid treatment and methane leakage, the above laws and related discharge standards are hard to meet in practice [34].

In contrast to China, the laws and regulations by federal or state government of the United States cover almost all aspects of the lifecycle of shale gas development, from well site preparation to site restoration, from well drilling and fracturing to well plugging, and from water withdraw to waste disposal. If not enough attention is paid to environmental issues, the development of the shale gas industry would be seriously hindered. For example, out of the potential pollution by hydraulic fracturing, Germany restricts the development of shale gas, and only experimental production under certain conditions is allowed.

\subsubsection{Weak Policy Stimulus}

At present, policies that provide direct subsidies may be the most attractive. In 2012, MOF and NEA issued the Notice on Introduction of Financial Subsidy Policy for Shale Gas Development and Utilization. According to this policy, companies would receive a subsidy of $0.4 \mathrm{CNY} / \mathrm{m}^{3}\left(0.06 \$ / \mathrm{m}^{3}\right)$ of shale gas production from 2012 to 2015, which is twice as much as the subsidy of CBM. This notice defines shale gas as it occurred in the source rock, with high organic matter content (total organic carbon must higher than $1.0 \%$ ), and the adsorption gas content is greater than $20 \%$; the interlayer's granularity is below and equal to siltstone or carbonate, and the thickness of a single layer does not exceed $1 \mathrm{~m}$; and the total thickness of the interlayer does not exceed $20 \%$ of the target layer of the gas 
well. According to MLR, the recoverable reserves of China reach $2510 \times 10^{9} \mathrm{~m}^{3}$. However, according to MOF's definition, only one-third of the total recoverable reserves can be recognized as "shale gas", which means companies engaged in shale gas development may not receive subsidies. Additionally, the Notice on Introduction of Financial Subsidy Policy for Shale Gas Development and Utilization also mentions that local governments can provide proper subsidies for local shale gas development and utilization based on specific conditions, but no policy of local subsidy has been published until now.

After the first round of subsidies, which expired in 2015, MOF issued Notice on Financial Subsidy Policy for Shale Gas Development and Utilization and continued to provide financial subsidies for shale gas. However, the subsidy standard of central government decreases to $0.3 \mathrm{CNY} / \mathrm{m}^{3}\left(0.05 \$ / \mathrm{m}^{3}\right)$ from 2016 to 2018 , and will further decrease to $0.2 \mathrm{CNY} / \mathrm{m}^{3}\left(0.03 \$ / \mathrm{m}^{3}\right)$ from 2019 to 2020 . Though drilling cost declines about $25 \%$, the actual comprehensive development cost is still very high. Additionally, oil and gas price is still low, so the gradually reducing subsidies will lower the attractiveness to potential investors.

Shale gas development requires a long-term investment, which means that after obtaining the exploration rights, it usually needs about three years to explore and construct, then gets stable production and subsidies. If firms engage in the shale gas industry after 2017, it would be impossible for them to produce shale gas stably before 2020. Since the new round of subsidies will expire in 2020, these firms have to take the risk of no subsidies. The expectation of uncertain subsidies also hinders some potential investors from entering China's shale gas industry.

\subsubsection{Inefficient Implementation of Policies}

According to Table 1, most of the policies are published in the form of "notice" and "opinion", which are at the macro level, and lack detailed implementation standards. Therefore, the firms engaged in the shale gas industry cannot fully enjoy the benefits offered by the policies in practice. For example, Shale Gas Industry Policy points out that the equipment which China cannot manufacture should be exempt from customs duty. However, the detail of this policy is still at the stage of research and discussion, and companies still need to pay customs duties for some key imported equipment. In contrast to coalbed methane, MOF, General Administration of Customs, and SAT jointly issued a Notice on the Import Tax Exemption for Imported Materials from CBM Exploration and Development Projects during the 13th Five-Year Plan Period, and a document of Exploration and Development of CBM Tax-Free Imported Materials List was attached to this notice.

In addition, shale gas producers need pipeline access to sell their products. However, due to historical reasons, most natural gas pipelines are monopolized by CNPC, Sinopec, and CNOOC, and it is hard for other gas producers to get access. To solve this problem, NEA and NDRC issued the Regulation on Openness of Oil \& Gas Pipeline Facilities (Trial) in 2014, to provide the unused capacity to new customers on a fair and nondiscriminatory basis. However, the full text of this policy did not mention any detailed quantitative indicators, or how to calculate the price of transportation. Additionally, this policy also does not describe some key issues clearly. For example, Article 5 mentioned that "if the oil and gas pipeline network facilities have surplus capacity, operators of the pipeline network facilities should open the pipeline network facilities to the third party market entities equally and provide services such as transportation, storage, gasification, liquefaction and compression", but the definition of "surplus capacity" has not been clarified. Therefore, this policy just conveyed the government's determination to reform oil and gas pipeline operations, but was still inadequate for a quantitative implementation standard.

\subsection{Suggestions on Policymaking and Implementation}

\subsubsection{Special Regulations for Hydraulic Fracturing and Water Use}

As the development scale is expanding and more companies are entering shale exploration and exploitation with insufficient experience, the environmental problems will be more serious. This paper 
suggests that the Chinese government should publish special environmental regulations and technical specifications for shale gas development and utilization.

Firstly, regulations and technical specifications for hydraulic fracturing need be issued as soon as possible. The government should clarify the toxic substances that are prohibited in fracturing, and force companies to open the chemical composition of fracturing fluid used in shale gas development. Moreover, an ecological compensation mechanism should be set up. By levying environment protection tax and water source tax, the local government could fund for restoring the ecological environment in shale gas development zones.

Secondly, the Chinese government should conduct a detailed strategic environmental assessment and formulate regulations for water use in shale gas development. As some studies suggested, a reasonable schedule for the water to be used for shale gas exploitation should be provided at first $[39,71]$. In shale gas exploration and production, the development scale must be determined strictly based on water resource, and the total amount of water used should be controlled. In addition, the water intake should avoid affecting the local residents' water use. Furthermore, for the ecologically fragile areas, a regional environmental impact assessment system should be established. If enterprises have begun to develop shale gas in ecologically fragile areas, the environmental impact should be assessed dynamically, and the development project should be suspended immediately once serious problems were found in the assessment.

Moreover, policymakers should pay attention to green technology R\&D and adoption, solving the environmental problems from the source. Since China's geological conditions are different from other countries and even more complex, some key green technologies must be independently developed. China should increase funding for clean production technology (e.g., substitutes for toxic chemicals in fracturing fluids, $\mathrm{CO}_{2}$ fracturing) and pollution prevention technology (e.g., wastewater treatment, groundwater pollution monitoring, methane leakage monitoring) R\&D. Furthermore, some finical instruments, such as green credit, and green industry development funds, can be used to support the adoption and application of green technology.

\subsubsection{Detailed Implementation Plans and Stable Subsidies}

According to the lifecycle of an industry, at the initial stage, the government should provide subsidies or policy support to lower the access threshold of the industry, in order to attract more companies. The more companies that participate, the more intense the competition. Thereafter, the competition will lead to technology innovation and cost reduction and, then, more companies will be attracted to enter. At present, the enthusiasm has been motivated by the prospect of shale gas and incentive policies but, still, very few companies actually participate in shale gas development, that is to say, there is not stiff competition. According to Figure 1, there are ten and fifteen policies corresponding to the cost issue and the market issue, and the key point of the future work is to refine these policies and provide detailed implementation plans. For example, for Policy No. 16 and No. 17, ENA and NDRC should develop a clear schedule and roadmap to open the oil and gas pipeline network, and really punish the giant state-owned oil companies who violate the policy provisions. Additionally, for the policy No. 21, the standards of acquiring subsidies should moderately reduce, so companies can easily enjoy the subsidy and benefits of policies. Thereafter, more companies will be driven to enter the shale gas industry.

In addition, the payback period of investment of oil \& gas exploration and exploitation is long, so the continuity of policy is very important, otherwise, investors are reluctant to do a long-term investment. Therefore, the Chinese government should maintain the subsidy standards or support expectation to attract multi-kinds of investors.

\subsubsection{More Communication and Better Supervision}

If the policymakers wish for their policies to get well-implemented, the stakeholders, such as enterprises, local governments, communities, and non-governmental organizations, should be 
introduced to the process of policymaking. Openness and transparency will provide an opportunity for social participation, and guarantee the fairness and effectiveness of the policies. Moreover, in the process of policy implementation, policy executor should actively communicate and interact with communities, non-governmental organizations, and other social organizations, enhancing mutual understanding and promoting policy implementation. Additionally, to avoid distorted implementation, it is necessary to pay attention to executors' quality improvement and professional training.

On the other hand, the central government always uses the tool of supervision to enhance the implementation of policies and regulations. By means of both incentive and accountability, the implementation of policy can be greatly improved. At present, however, a standard and effective supervision pattern still needs optimization. Finally, to ensure the implementation of the policies, the local governments where shale gas development is located should set up specialized agencies responsible for it.

\subsubsection{Information Sharing with a Public Big Data Platform}

In the United States, Energy Information Administration (EIA) has established a database, which contains information about the geological condition, reserve, production quantity, number of drilling wells, etc., and this database is available to the public. Industry and academia can use the database to support decision-making and policymaking. While, in China, except for large state-owned oil companies, such as CNPC and Sinopec, for other companies and academic institutions, it is hard to acquire data about shale gas development. This means that, even though companies get the exploration rights of certain blocks, they only have very limited geological data, so the exploration risk is very high. To some extent, a lack of necessary data may hinder more potential investors to enter the industry.

China State Council released the Internet Plus Action Plan [72] in 2015, aiming to integrate the Internet with traditional industries and fuel economic growth. Inspired by the concept of "Internet plus wind power" [73], this paper suggests that China should take advantage of the internet to promote basic data collection and sharing in the shale gas industry. Firstly, a data specification should be constructed to standardize the data in all sections of shale gas development, including exploration, exploitation, production, transportation, and sales. Then, a big data platform of "Internet plus shale gas" should be established to share information, which is open to both industry participators and academic researchers. By data mining and related research on this platform, some useful suggestions can be proposed, and even new business models would be created.

\section{Conclusions}

Based on the main problems that hindered the development of China's shale gas industry, this paper summarized the most relevant policies published in China from 2010 to 2016, and further analyzed their effectiveness. By statistics and analysis, eight government agencies have issued 25 policies to support and regulate the shale gas industry, and these policies have covered the main problems. Technology and market issues are most valued by policymakers, and there were fourteen and fifteen policies related to these two issues, respectively. Aided by the technology-related policies, several major research programs and 181 NNSFC research projects were approved from 2010 to 2016, and the total funding exceeded 350 million CNY ( $\$ 55$ million). Stimulated by the market-related and cost-related policies, the second round of shale gas exploration rights bidding attracted 83 enterprises, including 26 private companies to participate. These policies also attracted nine foreign companies (e.g., Shell, BP, Chevron, Total) to initiate thirteen international cooperation projects in the field of shale gas development from 2011. Due to the breakthrough in core technologies and increasing market activities, China's shale gas developing cost significantly reduced (e.g., the average drilling cost of horizontal well reduced by $23 \%$ ), and shale gas production increased at an average growth rate of $390 \%$, from 2012 to 2016. In 2016, China's shale gas production reached $7.88 \times 10^{9} \mathrm{~m}^{3}$, and became the third largest producer in the world. However, in contrast to the concerns about the technology and market issues, policymakers paid very limited attention to the environmental issues. Moreover, 
the policies still have some shortcomings in terms of stimulus intensity and policy implementation. In order to further promote China's shale gas industry, this paper suggests that China should formulate special environmental regulations and control shale gas development scale based on water resource, provide detailed implementation plans, and maintain stable subsidies, enhance communication and supervision, and establish a public big data platform.

In fact, this study still has some limitations. First, the effectiveness and deficiencies of the policies were analyzed and investigated without communicating with the policymakers and stakeholders. Second, though this paper has provided some practical implications, it lacks support from theories and models. In future work, we need to enhance this study with regard to the abovementioned aspects.

Author Contributions: All authors have worked on this manuscript together and all authors have read and approved the final manuscript. Z.W. and P.L. summarized the problems and collected the policies; Z.W., Y.L., and X.C. analyzed and discussed the policies effects; Z.W. and Y.L. wrote the paper.

Funding: This research was funded by National Natural Science Foundation of China (Grant Nos. 71501019, 71501138, 71601164 and 71502019), General Program of Development Research Center of Oil and Gas of Sichuan Province (Grant No. SKB17-01), China's Post-doctoral Science Fund Project (Grant No. 2018M631069), General Program of Education Department in Sichuan Province (Grant Nos. 16SB0071 and 16SB0049), Key Program of Resource-based City Development Research Center (Grant No. ZYZX-ZD-1701), General Program of Mineral Resources Research Center in Sichuan Province (Grant No. SCKCZY2014-YB04), Philosophy and Social Science Planning Program of Chengdu (Grant No. 2018A09), Soft Science Research Program of Chengdu (Grant No. 2017-RK00-00425-ZF) and Funding Program for Middle-aged Core Teachers of Chengdu University of Technology (Grant No. KYGG201519).

Acknowledgments: This work was supported partially by Special Funding for Post-doctoral Research Project of Sichuan in 2017 Named "Dynamic Evolution of Multi-System Coupling in Resource-Oriented Cities of Western China from Technology Innovation-Driven Perspective".

Conflicts of Interest: The authors declare that the grant, scholarship, and/or funding mentioned in the Acknowledgments section do not lead to any conflict of interest. Additionally, the authors declare that there is no conflict of interest regarding the publication of this manuscript.

\section{References}

1. British Petroleum. Statistical Review of World Energy 2018; British Petroleum: London, UK, 2018; pp. 1-56.

2. U.S. Energy Information Administration. Natural Gas Prices, Production, and Exports Increased from 2016 to 2017. Available online: https:/ / www.eia.gov/todayinenergy/detail.php?id=34532 (accessed on 23 September 2018).

3. Burnham, A.; Han, J.; Clark, C.E.; Wang, M.; Dunn, J.B.; Palou-Rivera, I. Life-Cycle greenhouse gas emissions of shale gas, natural gas, coal, and petroleum. Environ. Sci. Technol. 2012, 46, 619-627. [CrossRef] [PubMed]

4. Klein, D.E. $\mathrm{CO}_{2}$ emission trends for the US and electric power sector. Electr. J. 2016, 29, 33-47. [CrossRef]

5. U.S. Energy Information Administration. Technically Recoverable Shale Oil and Shale Gas Resources: An Assessment of 137 Shale Formations in 41 Countries Outside the United States. Available online: https:/ / www.eia.gov/analysis/studies/worldshalegas/pdf/overview.pdf (accessed on 14 July 2018).

6. Dong, D.; Zou, C.; Dai, J.; Huang, S.; Zheng, J.; Gong, J.; Wang, Y.; Li, X.; Guan, Q.; Zhang, C.; et al. Suggestions on the development strategy of shale gas in China. J. Nat. Gas Geosci. 2016, 1, 413-423. [CrossRef]

7. Dong, D.; Wang, Y.; Li, X.; Zou, C.; Guan, Q.; Zhang, C.; Huang, J.; Wang, S.; Liu, H.; Bai, W.; et al. Breakthrough and prospect of shale gas exploration and development in China. Nat. Gas Ind. B 2016, 3, 12-26. [CrossRef]

8. Zou, C.; Dong, D.; Wang, Y.; Li, X.; Huang, J.; Wang, S.; Guan, Q.; Zhang, C.; Wang, H.; Liu, H.; et al. Shale gas in China: Characteristics, challenges and prospects (II). Pet. Explor. Dev. 2016, 43, 182-196. [CrossRef]

9. China Geological Survey. China Shale Gas Resources Survey Report (2014). Available online: http:/ / www. cgs.gov.cn/upload/201506/20150610/20150624093321310.pdf (accessed on 14 July 2018).

10. Zou, C.; Zhao, Q.; Dong, D.; Yang, Z.; Qiu, Z.; Liang, F.; Wang, N.; Huang, Y.; Duan, A.; Zhang, Q.; et al. Geological characteristics, main challenges and future prospect of shale gas. J. Nat. Gas Geosci. 2017, 2, 273-288. [CrossRef] 
11. Liao, Y.; Luo, D.; Yuan, J. A discussion on the relevant policies of stimulating the shale gas development in China. Nat. Gas Ind. 2012, 32, 1-5. (In Chinese)

12. Lin, W.; Liu, B. North American shale gas policy research findings. J. Tsinghua Univ. (Sci. Technol.) 2013, 53, 437-441, 446. (In Chinese)

13. Zhao, X.; Kang, J.; Lan, B. Focus on the development of shale gas in China-Based on SWOT analysis. Renew. Sustain. Energy Rev. 2013, 21, 603-613. [CrossRef]

14. Li, Y.B.; Li, Y.; Wang, B.; Chen, Z.; Nie, D. The status quo review and suggested policies for shale gas development in China. Renew. Sustain. Energy Rev. 2016, 59, 420-428. [CrossRef]

15. Geng, W. Study on tax and fee policies of shale gas exploration and development of the major Countries. Land Resour. Inf. 2016, 2, 8-14. (In Chinese)

16. Liu, Z.; Guo, J.; Wang, S.; Liu, H. Government incentive strategies and private capital participation in China's Shale gas development. Appl. Econ. 2018, 50, 51-64. [CrossRef]

17. Li, S.; Wang, P. Study on Supportive Policy of Shale Gas Exploration in China-A Case Study on Fuling National Shale Gas Demonstration Center. Nat. Resour. Econ. China 2015, 7, 44-47. (In Chinese)

18. Wu, Y.; Chen, K.; Yang, Y.; Feng, T. A system dynamics analysis of technology, cost and policy that affect the market competition of shale gas in China. Renew. Sustain. Energy Rev. 2015, 45, 235-243. [CrossRef]

19. Zhao, J.; Liu, C.; Yang, H.; Li, Y. Strategic questions about China's shale gas development. Environ. Earth Sci. 2016, 73, 6059-6068. [CrossRef]

20. Luo, Z.; Yang, K.; Cen, K.; Pan, H.; He, J.; Han, T. A study on the application of public-private partnership mode in shale gas development industry in China. J. Renew. Sustain. Energy 2018, 10, 045902. [CrossRef]

21. Krupnick, A.; Wang, Z.; Wang, Y. Environmental risks of shale gas development in China. Energy Policy 2014, 75, 117-125. [CrossRef]

22. Han, X.; Xiao, G. Research on water resources law and policy in shale gas development. J. Xi'an Jiaotong Univ. Soc. Sci. 2015, 35, 102-124. (In Chinese)

23. Yu, C.; Huang, S.; Qin, P.; Chen, X. Local residents' risk perceptions in response to shale gas exploitation: Evidence from China. Energy Policy 2018, 113, 123-134. [CrossRef]

24. Yuan, J.; Luo, D.; Xia, L.; Feng, L. Policy recommendations to promote shale gas development in China based on a technical and economic evaluation. Energy Policy 2015, 85, 194-206. [CrossRef]

25. Ma, Z.; Pi, G.; Dong, X.; Chen, C. The situation analysis of shale gas development in China-based on Structural Equation Modeling. Renew. Sustain. Energy Rev. 2017, 67, 1300-1307. [CrossRef]

26. Hu, D.; Xu, S. Opportunity, challenges and policy choices for China on the development of shale gas. Energy Policy 2013, 60, 21-26. [CrossRef]

27. Yang, Y.; Wang, L.; Fang, Y.; Mou, C. Integrated value of shale gas development: A comparative analysis in the United States and China. Renew. Sustain. Energy Rev. 2017, 76, 1465-1478. [CrossRef]

28. National Energy Administration; Ministry of Land and Resources; Ministry of Finance and Reform; National Development and Reform Commission. Shale Gas Development Plan (2011-2015). Available online: http: / / zfxxgk.nea.gov.cn/auto86/201203/t20120316_1454.htm (accessed on 28 September 2018).

29. Zhang, D. The current state in China of shale gas exploration and development, and of external cooperation. Int. Pet. Econ. 2013, 7, 47-52, 111-112. (In Chinese)

30. Dong, D.; Zou, C.; Yang, H.; Wang, Y.; Li, X.; Chen, G.; Wang, S.; Lu, Z.; Huang, Y. Progress and prospects of shale gas exploration and development in China. Acta Pet. Sin. 2012, 33, 107-114. (In Chinese)

31. Lin, L.; Zhang, J.; Tang, X.; Jing, T.; Zhu, L. Conditions of continental shale gas accumulation in China. Nat. Gas Ind. 2013, 33, 35-40. (In Chinese)

32. Li, Y.; Nie, H.; Long, P. Development characteristics of organic-rich shale and strategic selection of shale gas exploration area in China. Nat. Gas Ind. 2009, 29, 115-118, 152. (In Chinese)

33. Zhang, J.; Jiang, S.; Tang, X.; Zhang, P.; Tang, Y.; Jing, T. Accumulation types and resources characteristics of shale gas in China. Nat. Gas Ind. 2009, 29, 109-114, 151-152. (In Chinese)

34. Bloomberg New Energy Finance. China's Shale Gas Costs Are at Least Double Those in the US, but Rising Output Will Aid Its Bargaining Position in World Markets. Available online: https:/ / data.bloomberglp.com/ bnef/sites/4/2014/05/BNEF_PR_2014-05-29_China-shale-gas.pdf (accessed on 29 May 2014).

35. Sun, H. Roles and inspirations of SMEs in USA Shale Gas Revolution. Int. Financ. 2014, 9, 31-33. (In Chinese) 
36. National Energy Administration. Private Enterprises Enter the Energy Sector Need to Break through a Few Thresholds. Available online: http://www.nea.gov.cn/2014-01/15/c_133046732.htm (accessed on 15 January 2014).

37. Wang, D.; He, M. Impacts and suggestions of shale gas exploration and development on water. Environ. Sci. Surv. 2016, 35, 103-107. (In Chinese)

38. 21st Century Business Herald. Interview Jiao-Feng Guo, National Research Center of State Council: "13th Five-Year Plan" Should Reduce Water Resource Risk in Shale Gas Development. Available online: http: / / epaper.21jingji.com/html/2015-11/30/content_26825.htm (accessed on 30 November 2015).

39. Xie, H.; Ma, Z.; Wen, Z. Research on environmental policies for shale gas development in China. Environ. Prot. 2018, 1, 58-60. (In Chinese)

40. National Energy Administration. Notice on Establishment of 22 National Energy R\&D (Experimental) Centers. Available online: http:/ / www.nea.gov.cn/2013-10/14/c_132797218.htm (accessed on 28 September 2018).

41. Ministry of Land and Resources. Public Bidding for Mineral Exploration Rights of Oil \& Gas. Available online: http:/ / www.mlr.gov.cn/xwdt/jrxw/201107/t20110719_904591.htm (accessed on 28 September 2018).

42. Ministry of Land and Resources. Bulletin of New Discovered Mineral Species (No. 30 of 2011). Available online: http:/ / www.mlr.gov.cn/zwgk/zytz/201112/t20111231_1053403.htm (accessed on 28 September 2018).

43. National Development and Reform Commission; Ministry of Commerce. Catalogue for the Guidance of Foreign Investment Industries (Amended in 2011). Available online: http:/ / www.ndrc.gov.cn/fzgggz/ wzly/zhdt/201112/t20111229_453399.html (accessed on 28 September 2018).

44. Ministry of Land and Resources; All-China Federation of Industry and Commerce. Opinion on Further Encouraging and Guiding Private Capital Investment in the Field of Land and Resources. Available online: http:/ / www.mlr.gov.cn/zwgk/zytz/201206/t20120618_1111431.htm (accessed on 28 September 2018).

45. Ministry of Land and Resources. Notice on Agreeing to Establish 46 Key Laboratory of MLR. Available online: http:/ / www.mlr.gov.cn/zwgk/zytz/201206/t20120604_1106263.htm (accessed on 28 September 2018).

46. Ministry of Land and Resources. Announcement of Public Tender of Shale Gas Exploration Rights. Available online: http:/ / www.mlr.gov.cn/zwgk/zytz/201209/t20120910_1139187.htm (accessed on 28 September 2018).

47. Ministry of Land and Resources. Notice on Improving the Level of Mineral Resources Saving and Comprehensive Utilization by Promoting Advanced and Applicable Technologies. Available online: http:/ / www.mlr.gov.cn/zwgk/zytz/201210/t20121030_1151766.htm (accessed on 28 September 2018).

48. National Development and Reform Commission. The 12th Five-Year Plan of Natural Gas Development. Available online: http:/ / www.gov.cn/zwgk/2012-12/03/content_2280785.htm (accessed on 28 September 2018).

49. Ministry of Finance; National Energy Administration. Notice on Introduction of Financial Subsidy Policy for Shale Gas Development and Utilization. Available online: http:/ /www.gov.cn/zwgk/2012-11/05/content_ 2257957.htm (accessed on 28 September 2018).

50. Ministry of Land and Resources. Notice on Strengthening the Exploration \& Exploitation of Shale Gas and Relevant Supervision and Administration Work. Available online: http:/ /www.mlr.gov.cn/zwgk/zytz/ 201211/t20121122_1158928.htm (accessed on 28 September 2018).

51. Ministry of Finance; Ministry of Land and Resources. Notice on Issuing Special Funds Management Approach for Mineral Source Saving and Comprehensive Utilization. Available online: http:/ /www.mlr. gov.cn/xwdt/jrxw/201304/t20130415_1202858.htm (accessed on 28 September 2018).

52. State Taxation Administration. Announcement on Issues Concerning Value Added Tax Treatments Related to the Development of Coalbed Methane and Shale Gas by Oil and Gas Companies. Available online: http:/ / www.chinatax.gov.cn/n810341/n810765/n812146/n812338/c1081392/content.html (accessed on 28 September 2018).

53. National Energy Administration. Shale Gas Industry Policy. Available online: http:/ /zfxxgk.nea.gov.cn/ auto86/201310/t20131030_1715.htm (accessed on 28 September 2018).

54. National Energy Administration. Regulation on Openness of Oil \& Gas Pipeline Facilities (Trial). Available online: http:/ / zfxxgk.nea.gov.cn/auto92/201402/t20140224_1768.htm (accessed on 28 September 2018).

55. National Development and Reform Commission. Construction and Operation Management Measures of Natural Gas Infrastructure. Available online: http:/ / www.ndrc.gov.cn/ zcfb / zcfbl/201403/t20140320_ 603521.html (accessed on 28 September 2018). 
56. Ministry of Land and Resources. Technological Specification for Shale Gas Resources/Reserves Calculation and Evaluation. Available online: http://www.mlr.gov.cn/zwgk/zytz/201404/t20140421_1313335.htm (accessed on 28 September 2018).

57. General Office of State Council. Energy Development Strategy Action Plan (2014-2020). Available online: http:/ / www.gov.cn/zhengce/content/2014-11/19/content_9222.htm (accessed on 28 September 2018).

58. Ministry of Land and Resources. Bulletin of the Final Results of Expired Shale Gas Exploration Rights by Public Tender. Available online: http:/ /www.mlr.gov.cn/zwgk/zytz/201410/t20141031_1333935.htm (accessed on 28 September 2018).

59. Ministry of Finance; National Energy Administration. Notice on Financial Subsidy Policy for Shale Gas Development and Utilization. Available online: http:/ /jjs.mof.gov.cn/zhengwuxinxi/zhengcefagui/201504/ t20150427_1223392.html (accessed on 28 September 2018).

60. National Energy Administration. NEA Announcement No. 6 of 2015. Available online: http:/ / zfxxgk.nea. gov.cn/auto83/201511/t20151113_1974.htm (accessed on 28 September 2018).

61. State Council. The 13th Five-Year Plan of National Science \& Technology Innovation. Available online: http:/ / www.gov.cn/zhengce/content/2016-08/08/content_5098072.htm (accessed on 28 September 2018).

62. National Energy Administration. Shale Gas Development Plan (2016-2020). Available online: http:/ / www. gov.cn/xinwen/2016-09/30/content_5114313.htm (accessed on 28 September 2018).

63. National Development and Reform Commission. The 13th Five-Year Plan of Natural Gas Development. Available online: http:/ / www.ndrc.gov.cn/gzdt/201701/t20170119_835571.html (accessed on 28 September 2018).

64. Zou, C.; Yang, Z.; Zhu, R.; Zhang, G.; Hou, L.; Wu, S.; Tao, S.; Yuan, X.; Dong, D.; Wang, Y.; et al. Progress in China's unconventional oil \& gas exploration and development and theoretical technologies. Acta Geol. Sin. 2015, 89, 938-971. [CrossRef]

65. Jereh Oil and Gas Engineering Corporation. Jereh Operates China's Largest CO2 Fracturing Operation. Available online: http:/ / en.jerehepc.com/news/1284_for_news_text.htm (accessed on 29 August 2014).

66. Clayton, W.T. Policy Challenges to China's Shale Gas Industry. Master's Thesis, University of Texas at Austin, Austin, TX, USA, 2016.

67. BP Global. BP Signs Second Chinese Shale Gas Contract with CNPC. Available online: https://www.bp.com/ en/global/corporate/media/press-releases/bp-signs-second-chinese-shale-gas-contract-with-cnpc.html (accessed on 28 September 2018).

68. BP Global. BP and China National Petroleum Corporation Sign BP's First Shale Gas Production Sharing Contract in China. Available online: https:/ / www.bp.com/en/global/corporate/media/press-releases/bpand-china-national-petroleum-corporation-sign-shale-contract.html (accessed on 28 September 2018).

69. U.S. Energy Information Administration. Shale Gas Development in China Aided by Government Investment and Decreasing Well Cost. Available online: http:/ / www.eia.gov/todayinenergy / detail.php?id=23152 (accessed on 30 September 2015).

70. China News. China's Shale Gas Production Ranked the Third in the World in 2016. Available online: http:/ / www.chinanews.com/ny/2017/08-15/8305247.shtml (accessed on 15 August 2017).

71. Yu, S. Evaluation of socioeconomic impacts on and risks for shale gas exploration in China. Energy Strateg. Rev. 2015, 6, 30-38. [CrossRef]

72. The State Council, The People's Republic of China. China Unveils Internet Plus Action Plan to Fuel Growth. Available online: http:/ / english.gov.cn/policies/latest_releases/2015/07/04/content_281475140165588.htm (accessed on 25 July 2018).

73. Hou, J.; Zhai, X.; Liu, P. A review on China's wind power accommodation in the background of "Internet+" strategy. Int. J. Energy Res. 2018, 44, 1469-1486. [CrossRef]

(C) 2018 by the authors. Licensee MDPI, Basel, Switzerland. This article is an open access article distributed under the terms and conditions of the Creative Commons Attribution (CC BY) license (http:/ / creativecommons.org/licenses/by/4.0/). 